ROCZNIKI HUMANISTYCZNE

Tom LXVIII, zeszyt $6-2020$

DOI: http://dx.doi.org/10.18290/rh20686-6

TOMASZ LISOWSKI

\title{
LEKSEMY SWOISTE NOWEGO \\ TESTAMENTU BIBLII GDAŃSKIEJ (1632) \\ WOBEC LEKSYKI NOWEGO TESTAMENTU JAKUBA WUJKA (1593)
}

Leksemami swoistymi Nowego Testamentu Biblii gdańskiej (1632) są autosemantyczne hasła leksykonu tego tekstu, które nie wystąpiły w leksykonach trzech zestawianych z przekładem gdańskim z 1632 r. wcześniejszych renesansowych przekładów Nowego Testamentu, a mianowicie Nowego Testamentu Biblii brzeskiej (1563), Nowego Testamentu gdańskiego (1606) oraz Nowego Testamentu Biblii Jakuba Wujka (1599) (Lisowski, Sola Scriptura 241-242). Zestawienie tych tekstów miało na celu ocenę zależności filiacyjnej Nowego Testamentu Biblii gdańskiej od dwu pozostałych przekładów tradycji ewangelickiej (kalwińsko-luterańskiej i wspólnoty braci czeskich) przygotowywanych w zgodzie z doktrynalną zasadą sola Scriptura, czyli Nowego Testamentu Biblii brzeskiej (1563) i Nowego Testamentu gdańskiego (1606) (Lisowski, Sola Scriptura 159-160, 236-240). Uwzględnienie przekładu Nowego Testamentu Biblii Jakuba Wujka (1599) ukazało natomiast leksykalną zależność filiacyjną przekładu ewangelickiego z $1632 \mathrm{r}$. od jezuickiego przekładu z 1599 r. i pozwoliło ocenić jej zakres (Lisowski, Sola Scriptura 192-240). W tych badaniach jednak nie został uwzględniony Nowy Testament w przekładzie Jakuba Wujka z 1593 r., leksykalnie do pewnego stopnia odmienny od redakcji z $1599 \mathrm{r}$.

Biblia gdańska ukazała się Gdańsku, a wydała ją drukarnia Andrzeja Hünefelda. Był to przekład z języków oryginalnych na język polski w opracowaniu księdza Daniela Mikołajewskiego, duchownego i teologa reformowanego, seniora zborów na Kujawach (Sipayłło 154-156).

Prof. dr hab. ToMASZ LiSOwSKI - Zakład Lingwistyki Antropologicznej, Instytut Filologii Polskiej, Wydział Filologii Polskiej i Klasycznej Uniwersytetu im. Adama Mickiewicza w Poznaniu; adres do korespondencji: Instytut Filologii Polskiej UAM, ul. A. Fredry 10, 61-701 Poznań; e-mail: lisowski@amu.edu.pl; ORCID: https://orcid.org/0000-0001-6318-7421. 
Edycja ta powstała jako odpowiedź na zapotrzebowanie społeczne (Kossowska, Biblia, 2: 83). Już w końcu XVI wieku starsi Kościołów protestanckich - kalwińskiego, luterańskiego i braci czeskich, sygnatariuszy zgody sandomierskiej (denominacje uznające dogmat o Trójcy Świętej, przeciwstawiające się ideom antytrynitarskim braci polskich), byli przekonani o potrzebie opublikowania nowej edycji Pisma Świętego w języku polskim (Kossowska, Biblia, 2: 51). Wprawdzie do dyspozycji polskich ewangelików pozostawała opracowana w kręgu kalwińskim Biblia brzeska (1563), pierwsza translacja całości Pisma Świętego na język polski, której według deklaracji na karcie tytułowej dokonano z języków oryginalnych (Pietkiewicz, „Hebraica veritas" 219-220). Nad polskim tekstem tej edycji pracował zespół tłumaczy ${ }^{1}$, który zastosował naówczas nowoczesną technikę translacyjną zgodności co do sensu (Kwilecka, „Die Brester Bibel” 1522-1524). Efektem tego jest polszczyzna potoczysta, nienaganna, uwolniona od schematów składniowych języków podstawy (Kwilecka, Studia 173-176, 223). Te właściwości tekstu brzeskiego zjednywały powszechne uznanie dla tego przekładu, nawet u przedstawicieli kręgów obcych ideowo - szatę językową Biblii brzeskiej podziwiał m.in. jezuita Jakub Wujek (Kossowska, Biblia, 2: 100). Jednak odejście od dosłowności przekazu sensu biblijnego rodziło w środowisku protestantów obawy o wierność translacji brzeskiej z oryginalnymi tekstami podstawy przekładu (Kossowska, Biblia, 2: 90). A taki stan rzeczy ze względów doktrynalnych był nie do zaakceptowania. Dla protestantów bowiem jednym z pięciu filarów ich doktryny była zasada sola Scriptura, według której Biblia jest jedynym autorytetem w kwestii wiary, a indywidualna, samodzielna lektura Pisma jest bezpośrednim kontaktem wiernych z Bogiem (Oberman 131; Uglorz 126). Z tego względu koniecznością stało się przygotowanie nowej edycji Pisma Świętego, wolnej od zastrzeżeń o dowolność przekładu.

W zamierzeniu starszych Kościołów protestanckich nowa edycja Pisma Świętego miała być rewizją przekładu brzeskiego, polegającą na zestawieniu polskiego tekstu $\mathrm{z}$ oryginalnymi tekstami podstawy (w wypadku Nowego Testamentu z tekstem greckim) i wprowadzeniu emendacji tam, gdzie pol-

\footnotetext{
${ }^{1}$ Inicjatorem tej edycji był Jan Łaski, a koordynatorem prac był Grzegorz Orszak, a następnie Jerzy Schomann. W skład zespołu tłumaczy w różnym czasie wchodzili: Jakub Lubelczyk, Andrzej Trzecieski, Szymon Zacjusz, Marcin Krowicki, Grzegorz Paweł z Brzezin, a także Franciszek Lismanin, Jerzy Blandrata, Franciszek Stankar. Przy przekładzie jako konsultanci i znawcy problematyki biblijnej pracowali także przybyli ze Szwajcarii Francuzi - Piotr Statorius i Jan Thénaud z Bourges, wychowanek Jana Kalwina. Protektorat nad pracą tego zespołu, a następnie nad wydaniem Biblii objął Mikołaj Radziwiłł Czarny (Kwilecka, Die Brester Bibel 1489, 1533; Frick, The Brest Bible 1661, 1679-1680).
} 
skie tłumaczenie nie w pełni adekwatnie oddawało sens oryginalnego przekazu biblijnego. Ambicją zleceniodawców było także, by nowa polska edycja ewangelicka Pisma Świętego stała się kanonicznym przekładem na język polski, czyli wernakularną wulgatą (Winiarska-Górska, Szesnastowieczne przekłady 121-127 i „Wulgata”) o prestiżu przewyższającym ten, jakim zaczynała się cieszyć wydana drukiem w ostatnim roku XVI wieku Biblia w opracowaniu jezuickim, znana jako Biblia Jakuba Wujka² (1599) (Frick, Polish Sacred Philology 226), której podstawą przekładu zgodnie z zaleceniami eklezjalnymi była łacińska Wulgata, w jej potrydenckiej redakcji, autoryzowanej przez papieża Klemensa VIII, znanej jako Vulgata Clementina (1592) (Smereka VII-XLVIII; Czerniatowicz 70-84).

W prace nad nową wersją polskiego przekładu Pisma Świętego, która miała objąć w pierwszej kolejności Nowy Testament, a następnie Stary Testament, mieli być zaangażowani przedstawiciele wszystkich trzech wyznań ewangelickich w Koronie i w Wielkim Księstwie Litewskim - a więc luteranie, kalwini i bracia czescy. Ostatecznie decyzją konwokacji generalnej w Baranowie 3 maja 1604 r. Daniel Mikołajewski, minister kalwiński z Radziejowa, oraz Jan Turnowski, superintendent braci czeskich w Wielkopolsce, zostali wyznaczeni do rewizji Biblii brzeskiej. W swoich pracach mieli oni wykorzystać poza biblijnymi tekstami oryginalnymi także Biblię w języku czeskim - prawdopodobnie Biblię kralicka (Frick, Polish Sacred Philology 227) - oraz Wulgate (Sipayłło, „W sprawie genezy” 145-150), a także być może niedochowany do dziś i bliżej nieznany przekład polski Marcina Janic$\mathrm{kiego}^{3}$. Efektem tych prac emendacyjnych, a właściwie redakcyjnych, jest Nowy Testament gdański (1606). Mimo że edycja gdańska Nowego Testamentu w zamierzeniu jej zleceniodawców miała być tylko rewizją tekstu brzeskiego z roku 1563, to jednak, jak dowodzą ostanie badania, leksykalnie odbiega ona od tekstu wcześniejszego, zarówno pod względem kwantytatywnym, jak i jakościowym (Lisowski, Sola Scriptura 77-79; 267-307 i „The lexis" 83-87). Choć w wielu miejscach biblijnych Nowego Testamentu gdańskiego ujawniają się nawiązania leksykalne do edycji brzeskiej (Lisowski,

\footnotetext{
${ }^{2}$ Przekład ten zwykło się przypisywać Jakubowi Wujkowi, jednak na jego ostateczny kształt językowy miała wpływ pięcioosobowa jezuicka komisja cenzorska, w skład której weszli: Justus Rab, Stanisław Grodzicki, Jan Brant, Marcin Łaszcz, Adrian Radzimiński. W jej pracach nie uczestniczył Jakub Wujek, a edycja Biblii ukazała się drukiem po jego śmierci (Kossowska, Biblia 1: 334-335).

${ }^{3}$ Przekład ten był gotowy przed rokiem 1600 (Sipayłło, „W sprawie genezy” 146), zaginął podczas dalszych prac nad Biblia gdańska (Kossowska, Biblia, 2: 95-96). Dokumenty synodalne po roku 1604 nie wspominają o nim jako o podstawie prac redakcyjnych (Czerniatowicz 89-91).
} 
„The lexis" 116-118), to wyraźnie uwidacznia się aprobatywna postawa jej redaktorów wobec podstawień leksykalnych przywołanych w jezuickich przekładach Nowego Testamentu Jakuba Wujka z 1593 i z 1599 r. Wprowadzane one są w tekście gdańskim jako substytuty leksemów przekładu brzeskiego w miejscach biblijnych niebędących nośnikami znaczeń istotnych doktrynalnie (Lisowski, Przektady 255-263).

Nowy Testament gdański (1606) spotkał się z chłodnym przyjęciem w środowisku ewangelickim, zbyt dalece bowiem odbiegał od formy językowej przekładu brzeskiego. Pilną potrzebą zatem było ponowne opracowanie edycji całości Biblii na podstawie tekstu Biblii brzeskiej (1563) (Sipayłło, „W sprawie genezy” 146; Kossowska, Biblia, 2: 89-95), którą mieli przygotować Daniel Mikołajewski i Jan Turnowski. Ostatecznie jednak - jak można przypuszczać - pracę wykonał samodzielnie Daniel Mikołajewski (Sipayłło, „W sprawie genezy” 146-150; Pietkiewicz, Biblia Polonorum, 1: 501-502). Prace nad przekładem Mikołajewski zakończył w 1623 r. Decyzją synodu wileńskiego z roku 1629, który mimo braku możliwości zapoznania się $\mathrm{z}$ tekstem Daniela Mikołajewskiego, zaakceptowano go in toto i skierowano do druku (Szeruda 24; Kossowska, Biblia 2: 88-89). Jak się okazało w 1632 r., gdy Biblia gdańska wyszła spod pras drukarskich, mimo zapewnień Daniela Mikołajewskiego, że poddał on ulepszeniom emendacyjnym przekład brzeski, efektem jego wieloletniej pracy okazał się autorski przekład Pisma Świętego (Wojak 44-45; Kępka 121-123). Co więcej, Daniel Mikołajewski nie inkorporował do edycji z 1632 r. tekstu Nowego Testamentu gdańskiego z roku 1606. Jak wskazują wyniki ostatnich badań, pod względem leksykalnym Nowy Testament wchodzący w skład Biblii gdańskiej jest tekstem oryginalnym, w dużym stopniu różnym od tekstu z 1606 r. (Lisowski, Sola Scriptura 241-279, 339).

Z drugiej strony, Nowy Testament wchodzący w skład Biblii gdańskiej genetycznie powiązany jest z wydanym w 1563 r. Nowym Testamentem Biblii brzeskiej oraz z opublikowanym w 1606 r. Nowym Testamentem gdańskim, w którego opracowaniu uczestniczył przecież Daniel Mikołajewski. Wszystkie te przekłady powstały w ewangelickim kręgu wyznaniowym, który spajała doktrynalna zasada sola Scriptura, w aspekcie prac nad przekładem Pisma Świętego na język wernakularny nakazująca wykorzystywać jako podstawę oryginalny tekst biblijny - w wypadku Nowego Testamentu tekst grecki Textus Receptus ${ }^{4}$. Daniel Mikołajewski posługiwał się jego wersją w opracowaniu Teodora Bezy (Czerniatowicz 98, 100-101).

\footnotetext{
${ }^{4} \mathrm{~W}$ analizach posługuję się tekstem Textus Receptus 1550.
} 
Wszystkie te względy decydują o tym, że jak dowodzą wyniki porównawczych badań jakościowych nad leksyką autosemantyczną tych translacji, Nowy Testament Biblii gdańskiej wykazuje leksykalne zależności filiacyjne z tekstem brzeskim z 1563 r. i z Nowym Testamentem gdańskim z 1606 r. (Lisowski, Sola Scriptura 159-191, 236-240 i „The lexis” 75-118). Wyniki tych badań, w których uwzględniono także Nowy Testament Biblii Jakuba Wujka z roku 1599, ujawniają także zależność leksykalną ewangelickiej translacji gdańskiej z 1632 r. od jezuickiego przekładu z 1599 roku (Lisowski, Sola Scriptura 159-160, 192-240). Podobnie jak w przypadku prac nad Nowym Testamentem gdańskim, przy opracowywaniu Biblii gdańskiej Daniel Mikołajewski posługiwał się czeskim przekładem Pisma Świętego. Zapewne była to Biblia kralicka (1579-1593), którą opracowano w kręgu wspólnoty braci czeskich (Szeruda 28-29). Wyniki badań leksyki Nowego Testamentu tych dwu tekstów zdają się to twierdzenie wspierać dowodami empirycznymi (Lisowski, Sola Scriptura 351-387).

Biblia gdańska $(1632)^{5}$ jawi się zatem jako ostatnia renesansowa translacja Pisma Świętego powstała w tradycji ewangelickiej. Nowy Testament tego przekładu leksykalnie zależny jest do pewnego stopnia od Nowego Testamentu Biblii brzeskiej $(1563)^{6}$ oraz od Nowego Testamentu gdańskiego $(1606)^{7}$, tekstów zredagowanych w tym kręgu doktrynalnym, ale także od Nowego Testamentu Biblii Jakuba Wujka z 1599 r. ${ }^{8}$ Zestawienie leksykonów tych czterech translacji pozwoliło m.in., jak już wspomniano, na wyłonienie autosemantycznych leksemów swoistych $G$, czyli haseł niewystępujących w leksykonach $B, N$ oraz $W$. Dowodzą one, że Daniel Mikołajewski w swoich wyborach leksykalnych niekiedy rezygnował z ekwiwalentów przywołanych $\mathrm{w}$ dwu przekładach tradycji ewangelickiej czy też $\mathrm{w} W$, przekładzie jezuickim. Nie oznacza to jednak, że leksemy swoiste $G$ nie wchodzą w skład leksykonów innych nieuwzględnionych w tym zestawieniu wcześniejszych renesansowych translacji Nowego Testamentu na język polski.

Celem prezentowanej analizy jest skonfrontowanie leksemów swoistych $G$, będących w konkretnych miejscach biblijnych polskimi ekwiwalentami leksemów greckiej podstawy przekładu, z ich odpowiednikami Nowym Testa-

\footnotetext{
${ }^{5}$ Odtąd, pisząc o Nowym Testamencie Biblii gdańskiej (1632), posługiwał się będę skrótem - $G$.

${ }^{6}$ Odtąd, pisząc o Nowym Testamencie Biblii brzeskiej (1563), posługiwał się będę skrótem - $B$.

${ }^{7}$ Odtąd, pisząc o Nowym Testamencie gdańskim (1606), posługiwał się będę skrótem $-N$.

${ }^{8}$ Odtąd, pisząc o Nowym Testamencie Biblii w przekładzie Jakuba Wujka i w opracowaniu Komisji Jezuickiej (1599), posługiwał się będę skrótem - $W$.
} 
mencie Jakuba Wujka z 1593 r. ${ }^{9}$ Wydaje się to o tyle uzasadnione, że po pierwsze, ten przekład Jakuba Wujka leksykalnie różni się w wielu miejscach biblijnych od późniejszej redakcji Nowego Testamentu, która weszła w skład Biblii z 1599 r.; po drugie, przekładu tego Jakub Wujek dokonał wprawdzie z łacińskiej Wulgaty, ale - jak sam deklarował - w swojej pracy translacyjnej odwoływał się do oryginalnego tekstu greckiego, co w oczach ewangelików musiało zyskać uznanie; po trzecie, do tego przekładu niekiedy niezależnie od $W$ odwoływali się w swoich pracach emendacyjnych redaktorzy N, Jan Turnowski i Daniel Mikołajewski (Lisowski, Przekłady 133-139, 157-163,191-192, 255-263). Analiza ma charakter dystrybucyjno-konteksto$w^{10}$. Polega na zestawieniu leksemów swoistych występujących w konkretnych miejscach biblijnych tekstu $G$ jako ekwiwalentów leksemów greckiej podstawy przekładu z ich odpowiednikami przywołanymi w tych miejscach biblijnych w tekście $Q$. Nawet jeśli przyjąć, że $Q$ to tekst ostatecznie przekładany z łacińskiej Wulgaty, proponowana procedura jest uzasadniona, a to dlatego że łaciński leksem, a w konsekwencji także jego polskie podstawienie przytoczone w $Q$, jest ekwiwalentem leksemu greckiej podstawy Wulgaty. Efektem takiego postępowania empirycznego jest próba odpowiedzi na pytanie o stopień zależności leksykalnej $G$ od $Q$ w zakresie leksyki swoistej.

Na leksykon $G$ składa się 338 leksemów swoistych ${ }^{11}$, co stanowi 6,6\% słownika $G$, które zostały użyte w tekście 522 razy, co stanowi $0,4 \%$ tekstu $G$ (Lisowski, Sola Scriptura 241). Innymi słowy leksemy swoiste $G$ pojawiły się w tym tekście w 522 miejscach biblijnych. Zestawienie ich oraz ich alternatywnych odpowiedników w tekstach $B, W, N$ z podstawieniami w tekście $Q$, co stanowi novum tej analizy, wykazało, że w 82 spośród 522 uwzględnianych miejsc biblijnych Daniel Mikołajewski w swoich poszukiwaniach najbardziej adekwatnego polskiego odpowiednika leksemu greckiej podstawy mógł skorzystać z leksemów przytoczonych w tekście $Q$. W tych miejscach biblijnych bowiem podstawienia wprowadzone przez Jakuba Wujka do tekstu $Q$ różnią się pod względem jakościowym od podstawień w $B, W$ i $N$. Mogły więc one stanowić źródło leksyki swoistej tekstu $G$, oczywiście w przyjętym w tej analizie rozumieniu. Ostatecznie jednak w zakresie leksemów swoistych tek-

\footnotetext{
${ }^{9}$ Odtąd, pisząc o Nowym Testamencie w przekładzie Jakuba Wujka (1593), posługiwał się będę skrótem $-Q$.

${ }^{10}$ Szerzej na temat założeń analizy dystrybucyjno-kontekstowej zob. Lisowski, Przekłady 25-40.

${ }^{11}$ Pełne zestawienie autosemantycznych leksemów swoistych wraz z podaniem ich lokalizacji, greckich leksemów podstawy, dla których są polskimi ekwiwalentami, wraz z ich znaczeniem w tekście nowotestamentowym oraz alternatywnych podstawień przywołanych w tekstach $B, W$ i $N$ przedstawione zostało w monografii Tomasza Lisowskiego (Sola Scritura 242-266).
} 
stu $G$ aż w 59 miejscach biblijnych spośród 82 Daniel Mikołajewski wprowadza do swojego tekstu podstawienia nietożsame z tymi przywołanymi w tekście $Q$. Uznać zatem należy, że w wypadku tych 59 miejsc biblijnych, w których wystąpiło 56 leksemów alternatywnych wobec tych przywołanych w tekstach $B, W$ i $N$, tekst $Q$ nie był dla Daniela Mikołajewskiego wzorcem rozstrzygnięć w zakresie leksyki jego przekładu. Dystrybucja polskich ekwiwalentów w tych miejscach biblijnych, w których Daniel Mikołajewski mógł skorzystać z podstawień leksykalnych przywołanych w Q, ale jednak przed tym się powstrzymał, w szczegółach wygląda następująco:

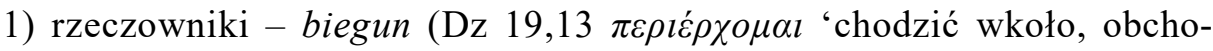

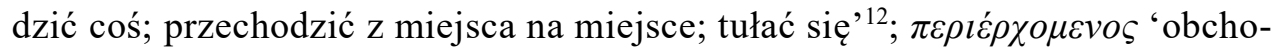
dzący wkoło'; B tułak; $Q$ ten, co włoczy się; W włóczacy się; $N$ tułacz),

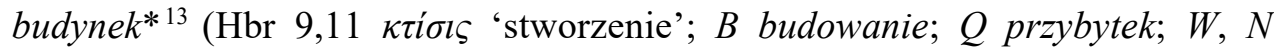
stworzenie), ciśnienie ( $\lfloor\mathrm{k} 22,41 \beta o \lambda \eta$ 'rzut'; $B, W, N$ jakoby mogt rzucić;

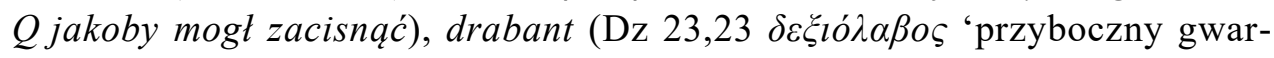
dzista, włócznik, oszczepnik'; $B$ drab; $Q$ pieszy z oszczepem; W oszczepnik;

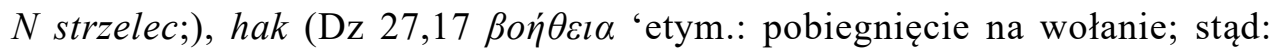
pomaganie, pomoc; 'pomaganie; prawdopod. termin techniczny oznaczający jakiś sprzęt ubezpieczający'; B Syrtyn; $Q$ wir; W Syrta; $N$ Syrtym), tajanie

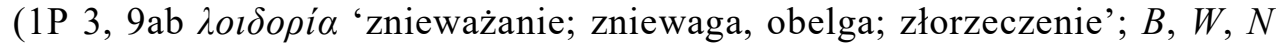

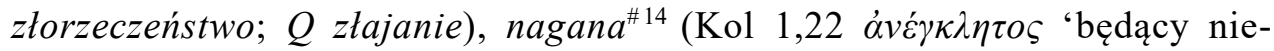
możliwym do objawienia; nienaganny'; $B, W, N$ naganiony; $Q$ niepokalany; 2P 3,14 $\dot{\alpha} \mu \omega ́ \mu \eta \tau o \varsigma ~ ' n i e n a g a n n y$, nieokryty hańbą'; B naganienie; $W, N$ nie-

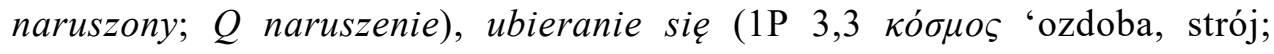
świat'; G ubieranie się w szaty; B obleczenie szat; $Q$ ubieranie szat; $W$ strojenie $w$ ubierze szat; $N$ strojenie $w$ obleczenie szat), ustuga* (Flp 2,17

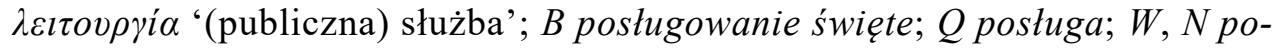

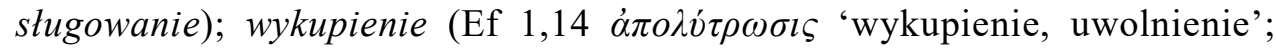
$\pi \varepsilon \rho \imath \pi о \imath \varepsilon о \mu \alpha l$ 'ocalać, zachowywać dla siebie, oszczędzać coś; zdobywać, zyskiwać, nabywać dla siebie coś'; $\alpha \pi \circ \lambda v \tau \rho \omega \sigma l \varsigma \tau \eta \varsigma \pi \varepsilon \rho \imath \pi o \imath \eta \sigma \varepsilon \omega \varsigma$ 'odkupienie pozyskania dla siebie'; G wykupienie nabytej własności; B przywieść ku

\footnotetext{
${ }^{12}$ Znaczenie leksemów greckich podaję za: Popowski, Wielki słownik grecko-polski Nowego Testamentu.

${ }^{13}$ Asteriks (*) oznacza, że omawiany leksem ma w tekście $G$ więcej poświadczeń niż te wskazane w omówieniu. Jednak w pozostałych miejscach jego występowania ekwiwalenty przywołane w $Q$ są tożsame z tymi, które zostały przywołane w $W$. Zatem nie spełniają warunków tej analizy.

${ }^{14}$ Leksem nagana ma 15 poświadczeń w tekście $G$, ale tylko w dwóch miejscach biblijnych jego odpowiedniki w tekście $Q$ są z nim tożsame (przykłady zostaną przywołane w dalszej części analizy). Symbol \# jest sygnałem takiego stanu rzeczy.
} 
wolności; $Q$ okup nabytej wolności; $W$ okup nabycia; $N$ okup nabycia), wytożenie (Hbr 5,11 $\delta v \sigma \varepsilon \rho \mu \eta \dot{v \varepsilon v \tau o \varsigma ~ ' t r u d n y ~ d o ~ w y ł o z ̇ e n i a, ~ t r u d n y ~ d o ~ w y j a s ́ n i e-~}$ nia'; $G$ trudny do wytożenia; $B, N$ trudno ku wykładaniu; $Q$ trudno wystowić; $W$ wyprawny ku mowieniu), zamyst* (Dz 8,22 Ėंivola 'myśl, pomysł'; $B, W, N$

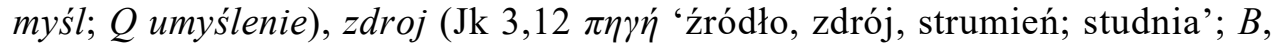

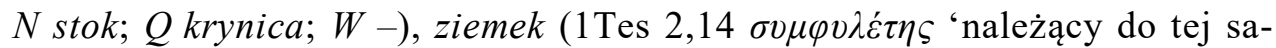
mej gminy; współziomek, rodak'; $B$ przyrodny; $Q$ narod; $W, N$ spotpokolennik), zwracanie (2P 2,22 غ́ं́ćs $\alpha \mu \alpha$ 'wymiociny'; B zmiecisko; $Q$ zrzucenie; $W, N$ zwrocenie);

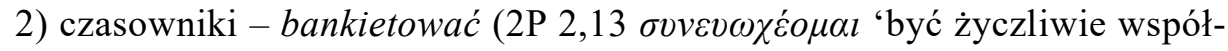
podejmowanym; współucztować, ucztować razem z kim'; $B, N$ biesiadować; $Q$ kochać się $w$ biesiadach; $W$ rozpustować $w$ biesiadach), buntujacy

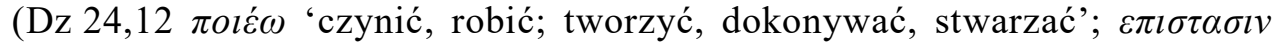

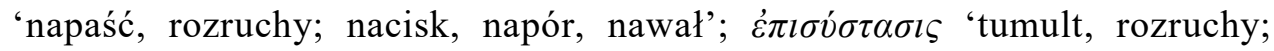
zgromadzenie'; G buntujacy lud; B, N czynić schadzki między ludem; $Q$ czyniacy rozruch miedzy rzesza; $W$ czynić konkurs ludu), dokazać* (Łk 1,51 $\pi$ đoléw 'czynić, robić; tworzyć, dokonywać, stwarzać'; $B$ sprawić; $Q w y$ -

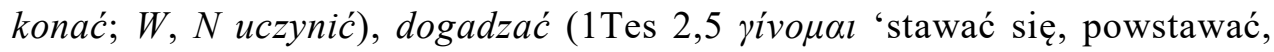
pojawiać się; spełniać się, dziać się, odbywać się, być wykonywanym, być stwarzanym; okazywać się'; $\pi \lambda \varepsilon o v \varepsilon \xi i \alpha$ 'obfitość; zachłanność'; G dogadzać lakomstwu; B zmyślać dla takomstwa; $Q$ być w podejźrzeniu lakomstwa; W być $w$ okazyjej takomstwa; $N$ używać takomstwa), dopetniać* (Mt 23,32 $\pi \lambda \eta \rho o ́ \omega$ 'czynić pełnym, napełniać; spełniać, wypełniać coś; dopełniać, koń-

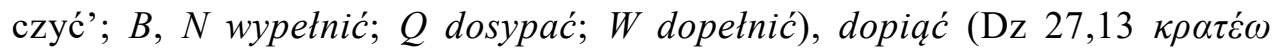
'brać w posiadanie; ująć, uchwycić; osiągnąć; podtrzymywać, trzymać; powstrzymywać, zatrzymywać, panować nad kimś'; aîp $\rho$ 'podnosić; brać; zabierać; usuwać; nieść'; $G$ dopiać swego przedsięwzięcia; $B, N$ dziać się wedle myśli; $Q$ przedsięwzięcie zdarzy się; W trzymać przedsięwzięcie), gromadzić się (Łk 11,29 غ̇ं $\alpha \theta \rho o i \zeta \omega$ 'gromadzić się, zbierać się w coraz większej liczbie, wciąż powiększać się’; B zejść się; $Q$ nabierać się; $W$ zbieżać; $N$ nagro-

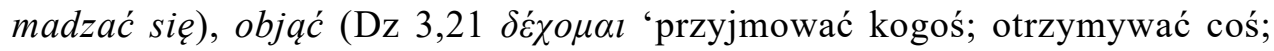
brać kogoś, coś do rąk; uznawać, akceptować'; $B$ być; ma być; $Q$ potrzeba, aby byt; $W, N$ przyjać), odmowic'* (Ap 10,4 $\lambda \alpha \lambda \varepsilon \dot{\varepsilon} \omega$ 'mówić'; $B, W, N$ mowić;

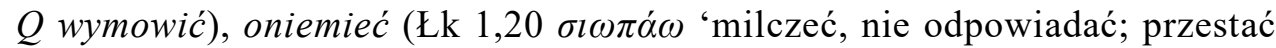
mówić, uspokoić się' $B$ zamilknaćc; $Q$ być milczacym; $W, N$ milczeć), ponosic'* (Jud 1,7 í $\pi \dot{\varepsilon} \chi \omega$ 'cierpieć, przechodzić przez co; wytrzymywać';

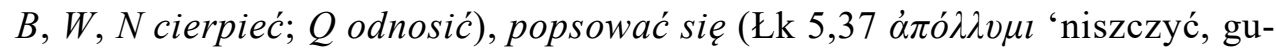
bić, zabijać, tracić; ginąć, umierać, przepadać, marnować się, psuć się; zaginąć, zatracić się, zagubić się'; B poginąć; $Q$ zepsuć się; $W$ obrocić się 
w niwecz; $N$ ginać), potłoczony (2Kor 4,8 $\sigma \tau \varepsilon v o \chi \omega \rho \varepsilon ́ \omega$ 'ściskać, ścieśniać, natłoczyć; być ściśniętym, być stłoczonym, być w ciasnocie, być ograniczonym'; $B, W, N$ ścieśniony; $Q$ być przywiazany), pozbawion (1Tes 2,17 $\dot{\alpha} \pi о \rho \varphi \alpha v i \zeta \omega$ 'osierocić'; $B, N$ osirociaty; $Q$ osierociaty; $W$ opuszczony), rozgłoszony* (Łk 1,65 $\delta l \alpha \lambda \alpha \lambda \dot{\varepsilon} \omega$ 'omawiać'; $B, W, N$ rozsławić; $Q$ rozsławiony),

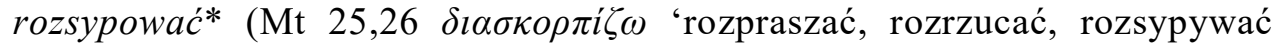
coś; roztrwonić, trwonić coś'; $B, W, N$ rozpraszać; $Q$ rozproszyć), rozplynać się (2P 3,11 $\lambda v \omega$ 'rozwiązywać, uwalniać; niszczyć, burzyć; znosić, obalać coś'; B rozstapić się; $Q$ roztajać; $W, N$ zepsować się), szczycić się (1Tm 6,21

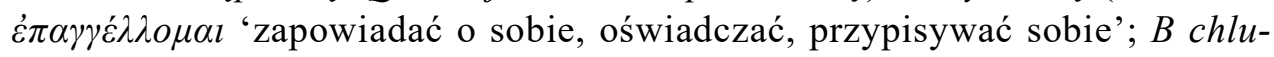
bić się; $Q$ popisować się; $W, N$ obiecywać), szkalować (Rz 3,8 $\beta \lambda \alpha \sigma \varphi \eta \mu \varepsilon ́ \omega$ 'etym. prawd.: krzywdząco mówić; stąd: bluźnierczo mówić, bluźnić, przeklinać, lżyć, spotwarzać, urągać komuś'; $B$ mowić; $Q$ mowić źle; $W, N$ bluźnić), trapić się* (Mt 8,6 $\beta \alpha \sigma \alpha v i \zeta \omega$ 'trzeć o probierczy kamień; stąd: torturować, męczyć, dręczyć, nękać, zadawać katusze, katować'; $B, W, N$ być tra-

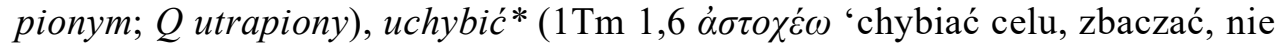
trafiać'; $G$ uchybić celu; $B$ ubtadzić; $Q$ odstrzelić się; $W, N$ obładzić się),

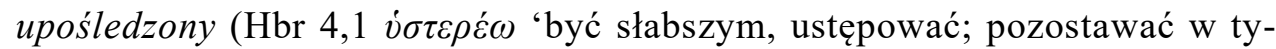
le, spóźniać się'; $B, N$ być omylonym; $Q$ pozostać; $W$ że go nie masz), uprzątniony (1Kor 5,2 aîp $\rho$ 'podnosić; brać; zabierać; usuwać; nieść'; $B, N$ odjęt;

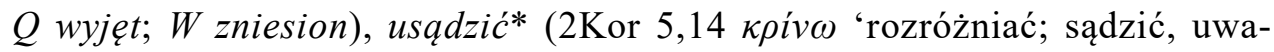
żać; postanawiać; rozsądzać, sądzić, skazywać; pozywać; osądzać'; $B$ postanowić; $Q$ uważajacy; W uważać; $N$ uważyć), wyprostować się (1Tes 3,11 $\kappa \alpha \tau \varepsilon v \theta v v \omega \omega$ 'czynić prostym; torować, prowadzić prosto, prowadzić coś'; $B, N$ wyprostować; $Q$ sprawić; $W$ prostować), zabawiać sie (1Tm 4,15 eimi 'być; istnieć, żyć'; B zostać; $Q$ sprawować się; W obierać się; $N$ być), zachwiany (Ap 6,13 $\sigma \varepsilon i \omega$ 'potrząsać, wstrząsać czymś; być potrząsanym, być wstrząśniętym, poruszyć się, zadrżeć'; $B, W, N$ zatrząść; $Q$ zatrzęsiony), za-

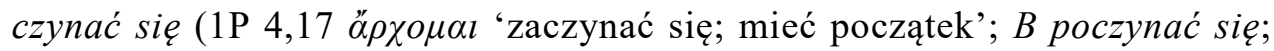

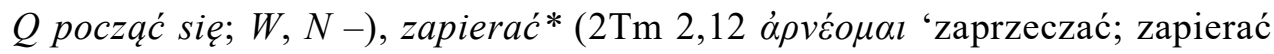
się, wypierać się, wyrzekać się kogoś, czegoś'; $B, N$ przeć; $Q$ zaprzeć się; $W$ zaprzeć), zazielenić się (Flp 4,10 $\dot{\alpha} v \alpha \theta \dot{\alpha} \lambda \lambda \omega$ 'doprowadzić do ponownego rozkwitu; rozwijać'; $B$ oświeżéc; $Q$ rozkwitnać; $W, N$ zakwitnać), zjadać

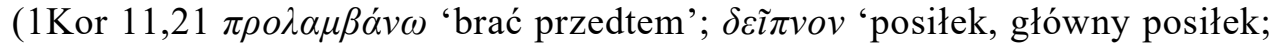
wieczerza; obiad'; $G$ zjadać wieczerzę; $B$ używać wieczerzy; $Q$ używanie

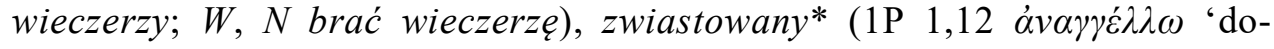
nosić, oznajmiać, ujawniać coś komuś; zdawać sprawę, opowiadać o czymś';

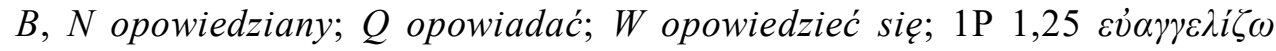
'nieść dobrą nowinę, zwiastować dobrą nowinę, nieść radosną wieść; głosić 
jako dobrą nowinę coś komuś; zwiastować, ogłaszać coś komuś; głosić ewangelię, głosić radosną nowinę o czymś’; $B, W, N$ przepowiedziany; $Q$ przepowiadany);

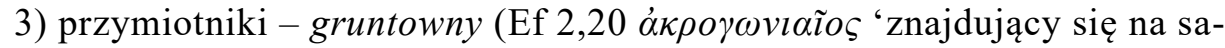
mym rogu, węgielny; subst.: narożnik'; B kamień węgłowy; $Q$ kamień przedniejszy węgłowy; $W$ kamień głowny węgielny; $N$ kamień przedniejszy węgielny;

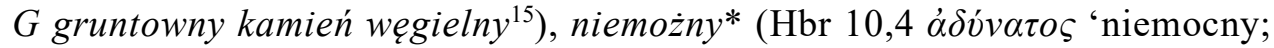
niemożliwy'; B nie moc; $Q$ nie być podobny; $W$ niepodobna; $N$ nie można

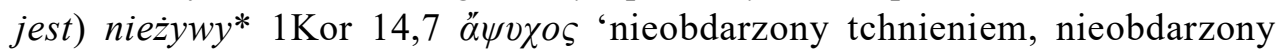
duszą, nieożywiony; o instrumentach muzycznych'; $B, W, N$ nie mieć dusze;

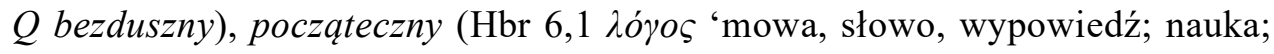

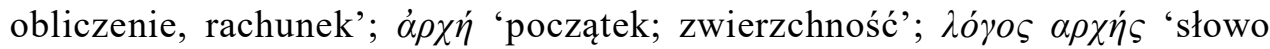
początku'; B słowo ktore dawa początek nieumiejętnym; $Q$ mowa o poczatku; $W$ mowa poczynania; $N$ poczatek mowy; $G$ poczateczny nauka), powiadomy* (Mt 22,29 oĩ $\delta \alpha$ 'wiedzieć, znać, umieć, potrafić; rozumieć, pojmować; pamię-

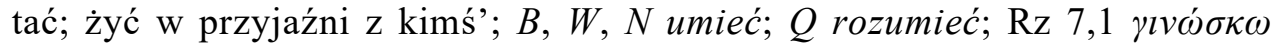
'poznawać, znać; rozpoznawać, uznawać; dowiedzieć się; wiedzieć; rozumieć, pojmować, zauważać; umieć'; $B$ uczony; $Q$ umieć; $W, N$ umiejacy), rozpustny* (2P 2,7 $\dot{\alpha} v \alpha \sigma \tau \rho o \varphi \eta ́$ 'obracanie się; stąd: sprawowanie się, postępowanie, zachowywanie się, sposób życia'; B obcowanie bezecne; $Q$ obcowanie plugawe; $W$ obcowanie sprosne; $N$ obcowanie $w$ niepościagliwości; G obcowanie rozpustne);

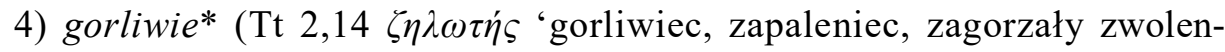
nik, zagorzały wyznawca, zelota, entuzjasta'; G naśladujacy gorliwie; $N$, B naśladujacy; $W$ naśladowca; $Q$ obierajacy się chętliwie); spornie Flp 2,3 É $\rho \imath \theta \varepsilon i \alpha$ 'etym.: postępowanie na sposób najemnika; stąd prawd.: przekora, kłótliwość; intrygowanie'; $B$ przez swar; $Q$ przez poswarki; $W, N$ przez

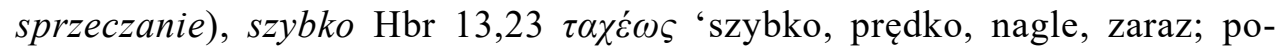
chopnie, pośpiesznie'; $B, W, N$ rychło; $Q$ krotko).

Wcześniejsze badania nad leksyką $G$ (Lisowski, Sola Scriptura 351-387) pozwalają stwierdzić, że w 16 spośród tu analizowanych 59 miejsc biblijnych, w których wzorcem translatologicznych rozwiązań leksykalnych dla Daniela Mikołajewskiego mógłby być tekst $Q$, ekwiwalenty przywołane w $G$ zgodne są z ich odpowiednikami w Nowym Testamencie czeskiej Biblii kralickiej ${ }^{16}$.

\footnotetext{
${ }^{15} \mathrm{Na}$ temat genezy frazeologizmu biblijnego kamień węgielny i jego losów w polskich przekładach nowotestamentowych wyczerpująco pisał Stanisław Koziara (Frazeologia 85-87 i Tradycyjne biblizmy 24, 92-93, 193, 210).

${ }^{16}$ Odtąd, pisząc o Nowym Testamencie Biblii kralickiej (1594), posługiwał się będę skrótem - K
} 
Są to:

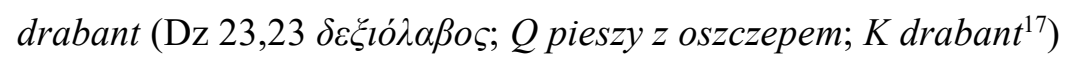

$G$ A zawoławszy dwoch niektorych z setnikow, rzekł: Nagotujcie dwieście żołnierzy, aby szli aż do Cezaryi, do tego siedmdziesiąt jezdnych i dwieście drabantow na trzecią godzinę w nocy.

$K$ A zavolav dvou setníků, řekl jim: Připravte žoldnéřů dvě stě, aby šli až do Cesaree, a jezdců sedmdesáte, a drabantů dvě stě k třetí hodině na noc.

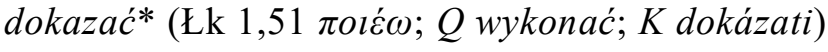

$G$ Dokazał mocy ramieniem swojem i rozproszył pyszne w myślach serca ich.

$K$ Dokázal moci ramenem svým, rozptýlil pyšné myšlením srdce jejich.

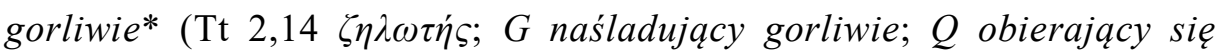
chętliwie; K následovný horlivě)

$G$ Ktory dał samego siebie za nas, aby nas wykupił od wszelkiej nieprawości i oczyścił sobie samemu lud własny, gorliwie naśladujący dobrych uczynkow.

$K$ Kterýž dal sebe samého za nás, aby nás vykoupil od všeliké nepravosti, a očistil sobě samému lid zvláštní, horlivě následovný dobrých skutků.

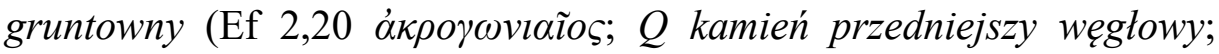
G gruntowny kamień węgielny; K gruntovni úhelný kámen),

$G$ Zbudowani na fundamencie Apostołow i prorokow, ktorego jest gruntownym węgielnym kamieniem sam Jezus Chrystus.

$K$ Vzdělaní na základ apoštolský a prorocký, kdežto jest gruntovní úhelný kámen sám Ježíš Kristus.

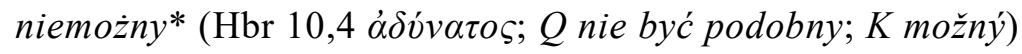

$G$ Albowiem niemożne jest, aby krew wołow i kozłow miała gładzić grzechy.

$K$ Nebot' možné není, aby krev býků a kozlů shladila hříchy.

odmowić* (Ap 10,4 $\lambda \alpha \lambda \varepsilon \dot{\varepsilon} \omega ; Q$ wymowić; Kodmluviti)

$G$ A gdy odmowiło siedm gromow głosy swoje, miałem pisać; alem usłyszał głos z nieba, mowiący do mnie: Zapieczętuj to, co mowiło siedm gromow, a nie pisz tego.

\footnotetext{
${ }^{17}$ Formy czeskie za opracowaniem Vokabulář webový.
} 
$K$ A když odmluvilo sedm hromů hlasy své, byl bych to psal. Ale slyšel jsem hlas s nebe řkoucí ke mně: Zapečet' to, co mluvilo sedm hromů, než nepiš toho.

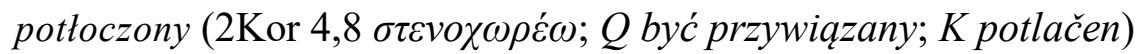

G Gdy zewsząd uciśnieni bywamy, ale nie bywamy potłoczeni; powątpiewamy, ale nie zwątpimy.

$K$ Myt' se všech stran úzkost máme, ale nebýváme cele potlačeni; v divných jsme nesnadnostech, ale nebýváme v tom pohlceni.

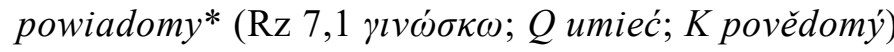

$G$ Azaż nie wiecie, bracia! (bo powiadomym zakonu mowię), iż zakon panuje nad człowiekiem, poki żyje?

$K$ Zdaliž nevíte, bratří, (nebo povědomým Zákona mluvím) že Zákon panuje nad člověkem, dokudž živ jest člověk?

rozgłoszony* (Łk 1,65 $\delta \imath \alpha \lambda \alpha \lambda \varepsilon ́ \omega ; Q$ rozsławiony; K rozhlásán)

$G$ I przyszedł strach na wszystkie sąsiady ich, i po wszystkiej gornej krainie Judzkiej rozgłoszone są wszystkie te słowa.

$K$ Tedy přišla bázeň na všecky sousedy jejich, a po všech horách Judských rozhlásána jsou všecka ta slova.

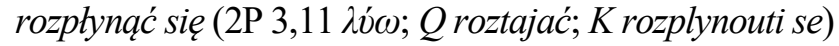

$G$ Ponieważ się tedy to wszystko ma rozpłynąć, jakimiż wy macie być w świętych obcowaniach i pobożnościach.

$K$ Poněvadž tedy to všecko má se rozplynouti, jací pak vy býti máte v svatých obcováních a v zbožnosti.

trapić się* (Mt 8,6 $\beta \alpha \sigma \alpha v i \zeta \omega ; Q$ utrapiony; K trápiti se)

$G$ I mowiąc: Panie! sługa moj leży w domu powietrzem ruszony, i ciężko się trapi.

$K$ A řka: Pane, služebník můj leží doma šlakem poražený, velmi se trápě.

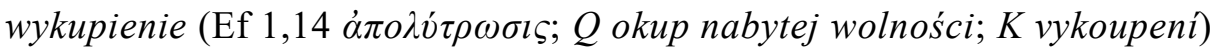

$G$ Ktory jest zadatkiem dziedzictwa naszego na wykupienie nabytej własności, ku chwale sławy jego.

$K$ Kterýž jest závdavek dědictví našeho, na vykoupení toho, což jím dobyto jest, k chvále slávy jeho. 


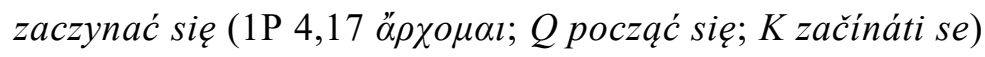

$G$ Albowiem czas jest, aby się sąd począł od domu Bożego. A ponieważ najprzod zaczyna się od nas, jakiż będzie koniec tych, co są nieposłuszni Ewangielii Bożej?

$K$ Nebot' jest čas, aby se začal soud od domu Božího. A poněvadž nejprv začíná se od nás, jakýž bude konec těch, kteříž nejsou povolni evangelium Božímu?

zapierać* $^{*}(2 \mathrm{Tm} 2,12$ ả $\rho v \varepsilon ́ o \mu \alpha l ; Q$ zaprzeć się; K zapíráti $)$

$G$ Jeśli cierpimy, z nim też krolować będziemy; jeśli go zapieramy, i on się nas zaprze.

$K$ A trpíme-lit', budeme také spolu s ním kralovati; pakli ho zapíráme, i ont' nás zapře.

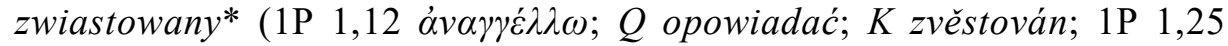

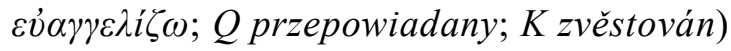

1P 1,12

$G$ Ktorym objawione jest, iż nie samym sobie, ale nam tem usługiwali, co wam teraz zwiastowano przez tych, ktorzy wam kazali Ewangieliję przez Ducha Świętego z nieba zesłanego, na ktore rzeczy pragną patrzyć Aniołowie.

$K$ Kterýmž zjeveno jest, že ne sobě, ale nám tím přisluhovali, což jest vám nyní zvěstováno skrze ty, kteříž vám kázali evangelium, v Duchu svatém seslaném s nebe, na kteréžto věci žádostivi jsou andělé patřiti.

1P 1,25

$G$ Ale słowo Pańskie trwa na wieki. A toć jest słowo, ktore wam jest zwiastowane.

K Ale slovo Páně zůstává na věky. Totot' pak jest to slovo, kteréž zvěstováno jest vám.

Daniel Mikołajewski, poszukując możliwie najbardziej adekwatnych polskich ekwiwalentów greckich leksemów podstawy przekładu, zapewne sięgał także do innych wcześniejszych polskich renesansowych translacji. W wypadku prac nad tekstem $N$ redaktorzy dysponowali na pewno przekładami Szymona Budnego i Marcina Czechowica, o czym wspominają w Przemowie do taskawego Czytelnika, poprzedzającej tekst Nowego Testamentu gdańskiego (1606):

Do czegośmy też innych tłumaczow przekładu jako Wujka, Budnego i Czechowica, gdzie się jaka rożność w tekście dawnym polskim pokazała, użyć nie zaniechali. $\mathrm{Z}$ tą jednak ochroną, żebyśmy wszędy za sznur a prawidło grecki autentyk mieli, ktorym językiem, jako to wszytkim wiadomo, księgi Nowego Testamentu 
od ewangelistow i apostołow pańskich napisane i Kościołowi Bożemu podane są (Nowy Testament gdański 2r).

Tymi przekładami zapewne dysponował także Daniel Mikołajewski, pracując nad Biblia gdańska. Dlatego wykluczyć nie można, że przynajmniej niektóre z przywołanych w $G$ w badanych tu miejscach biblijnych polskie podstawienia mogły zostać przejęte z któregoś z tych dwu translacji, powstałych $w$ tradycji antytrynitarskiej. Zagadnienie to niebędące przedmiotem tej analizy, zasługuje na odrębne opracowanie.

W wypadku pozostałych 23 miejsc biblijnych spośród tych 82, w których podstawienia leksykalne przywołane w tekście $Q$ są nietożsame z ich odpowiednikami w tekście $W$, a także w tekstach $B$ i $N$, przywołane w $G$ ekwiwalenty leksemów greckiej podstawy zdają się dowodzić, że źródłem rozstrzygnięć w zakresie doboru podstawień leksykalnych, jakich dokonywał Daniel Mikołajewski, mógł być tekst $Q$. Taką zależność wykazują 22 leksemy:

1) rzeczowniki

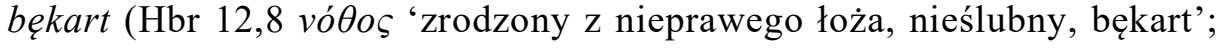
$B$ dziecko złego łoża; $W$ złe toże; $N$ nieczyste toże)

$Q \quad$ A jeśli jesteście bez karania, ktorego stali się wszyścy uczestnikami, tedyście bękarty, a nie synami.

$G$ A jeźli jesteście bez karania, ktorego wszyscy są uczestnikami, tedy jesteście bękartami, a nie synami.

$B \quad$ A jesli jesteście bez karania, ktorego wszyscy są uczestnikami, już złego łoża dziećmi jesteście, a nie synmi.

$W$ A jeśli jesteście bez karania, ktorego stali się wszyscy uczestnikami, tedyście złego łoża, a nie synami.

$N$ A jeśli jesteście bez karania, ktorego stali się wszyscy ucześnikami, tedyć nieczystego łoża jesteście, a nie synami.

lepianka ${ }^{18}(\mathrm{Rz} 9,20 \pi \lambda \dot{\alpha} \sigma \mu \alpha$ 'rzecz utworzona, rzecz uformowana, twór'; B rzecz ulepiona; $W, N$ rzecz lepiona)

$Q \quad$ O człowiecze, coś ty jest, ktory się spierasz z Bogiem? Zali lepionka rzecze lepiarzowi: Przecześ mię tak uczynił?

$G$ I owszem, o człowiecze! ktożeś ty jest, ktory spor wiedziesz z Bogiem? Izali lepionka rzecze lepiarzowi: Przeczżeś mię tak uczynił?

$B$ I owszem, o człowiecze! Ktożeś ty jest, ktory odpowiedasz naprzeciwko Bogu? Zali rzecz ulepiona powie temu, ktory ją ulepił: Przecześ mię tak uczynił?

${ }^{18} \mathrm{~W}$ tekście $Q$ występuje forma lepionka, którą Stownik polszczyzny XVI wieku uznaje za wariant hasła lepianka. 
$W$ O człowiecze, coś ty jest, ktory odpowiadasz Bogu? Zali rzecz lepiona mowi temu, ktory ją ulepił: Przeczżeś mię tak uczynił?

$N$ I owszem, o człowiecze, ktożeś ty jest, ktory odpowiadasz na przeciwko Bogu? Zali rzecz lepiona rzecze temu, ktory ją ulepił: Przeczżeś mię tak uczynił?

nagana (1Tm 6,14 $\dot{\alpha} v \varepsilon \pi i \lambda \eta \pi \tau o \varsigma$ 'niemożliwy do zaatakowania; nienaganny';

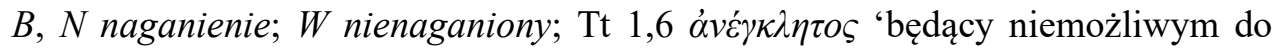
objawienia; nienaganny'; B przygana; $W$ wina; $N$ naganienie)

$1 \mathrm{Tm} 6,14$

$Q$ Abyś zachował to rozkazanie bez zmazy, bez nagany aż do przyścia Pana naszego Jezu Christa.

$G$ Abyś zachował to przykazanie, będąc bez zmazy, bez nagany, aż do objawienia Pana naszego, Jezusa Chrystusa.

$B$ Abyś zachował ty rozkazania, będąc bez zmazy i naganienia, aż do onego znacznego przyścia Pana naszego, Jezusa Krystusa.

$N$ Abyś zachował rozkazanie bez zmazy, bez naganienia aż do przyścia znacznego Pana naszego Jezusa Chrystusa.

$W$ Abyś zachował rozkazanie bez zmazy nienaganione aż do przyścia Pana naszego Jezusa Chrystusa.

Tt 1,6

$Q$ Jeśli kto jest bez nagany, mąż jednej żony, syny wierne mający, nieobwinowane w zbytku, abo niepoddane.

$G$ Jeźli kto jest bez nagany, mąż jednej żony, dzieci wierne mający, ktore by nie mogły być obwinione w zbytku, albo niepoddane rządowi.

$B$ Jesli kto jest krom naganienia, mąż jednej żony, dzieci wierne mając, nieobwinowane w zbytku, abo nieposłuszne.

$W$ Jeśli kto jest bez winy, mąż jednej żony, syny wierne mający, nieobwinowane w zbytku, abo niepoddane.

$N$ Jeśli kto jest krom naganienia, mąż jednej żonej, dzieci wierne mający, nieobwinione w zbytku abo niepoddane rządowi.

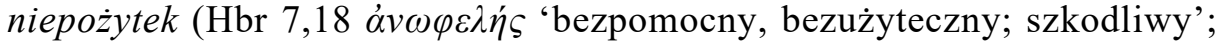
$B$ niepożyteczny; $W, N$ niepożyteczność)

$Q \quad$ Odrzucenie iście staje się przeszłego przykazania: dla słabości niepożytku jego.

$G$ Bo się stało zniesienie onego przyszłego przykazania dla słabości jego i niepożytku.

$B$ Bo rozkazanie przeszłe bywa zniszczone dla tego, iż żadnej mocy nie ma, a jest niepożyteczne.

$W$ Odrzucenie iście staje się przeszłego przykazania: dla słabości jego i niepożyteczności.

$N$ Bo odrzucenie staje się przeszłego przykazania dla słabości jego i niepożyteczności. 


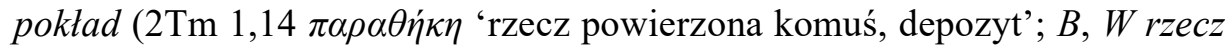
zwierzona; $N$ sktad)

$Q \quad$ Strzeż pokładu dobrego przez Ducha Ś., ktory w nas mieszka.

$G$ Strzeż dobrego pokładu przez Ducha Świętego, ktory w nas mieszka.

$B$ Zacną rzecz zwierzoną zachowaj przez Ducha świętego, ktory w nas mieszka.

$W$ Strzeż dobrej rzeczy zwierzonej przez Ducha ś., ktory w nas mieszka.

$N$ Strzeż składu dobrego przez Ducha Świętego, ktory w nas mieszka.

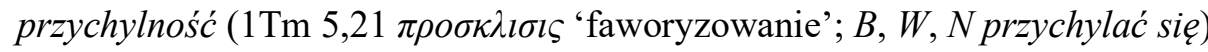

$Q$ Oświadczam się przed Bogiem i Christusem Jezusem i anioły wybranymi, abyś tego strzegł oprocz ubliżania, nic nie czyniąc z przychylności ku ktorej stronie.

$G$ Oświadczam się przed Bogiem i Panem Jezusem Chrystusem, i przed Anioły wybranymi, abyś tych rzeczy przestrzegał, w osobach nie brakując, nic nie czyniąc z przychylności.

$B$ Oświadczam się przed Bogiem i Panem Jezu Krystem i anioły wybranymi, abyś ty rzeczy zachował, nie przekładając jednego nad drugiego, nie czyniąc nic przychylając się ku ktorej stronie

$W$ Oświadczam się przed Bogiem i Chrystusem Jezusem i anioły wybranemi, abyś tego strzegł bez ubliżania, nic nie czyniąc, przychylając się do drugiej strony.

$N$ Oświadczam się przed Bogiem i Panem Jezusem Chrystusem, i anioły wybranemi, abyś tego strzegł bez skwapliwego sądu, nic nie czyniąc, przychylając się ku drugiej stronie.

siniałość (1P 2,24 $\mu \omega ́ \lambda \omega \psi$ 'ślad uderzenia, rana, siniec, pręga'; $B$ raz siniaty; $W, N$ siność $)$

$Q$ Ktory sam na ciele swym grzechy nasze nosił na drzewie, abyśmy umarwszy grzechom, żyli sprawiedliwości, ktorego siniałością jesteście uleczeni.

$G$ Ktory grzechy nasze na ciele swoim zaniosł na drzewo, abyśmy obumarłszy grzechom sprawiedliwości żyli, którego sinością uzdrowieni jesteście.

$B$ Ktory grzechy nasze nosił w ciele swoim na drzewie, abyśmy będąc umarłymi grzechom w sprawiedliwości żyli, ktorego siniałymi razy uzdrowieni jesteście.

$W$ Ktory sam na ciele swem grzechy nasze nosił na drzewie, abyśmy umarwszy grzechom, żyli sprawiedliwości, ktorego sinością jesteście uleczeni.

$N$ Ktory sam na ciele swym grzechy nasze nosił na drzewie, abyśmy obumarszy grzechom, sprawiedliwości żyli, ktorego sinością uleczeni jesteście.

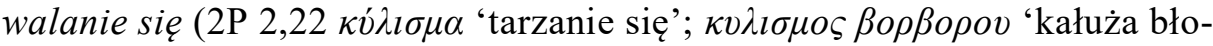
ta; tarzanie się w błocie'; $Q, G$ walanie się w błocie; $B, W, N$ katuża błota)

$Q$ Abowiem się im przydało wedle prawdziwej przypowieści: Pies, ktory się wrocił do zrzucenia swego, i świnia umyta do walania się w błocie. 
$G$ Aleć się im przydało według onej prawdziwej przypowieści: Pies wrocił się do zwracania swego, a świnia umyta do walania się w błocie.

$B$ Ale się im przydało, co prawdziwą przypowieścią pospolicie mawiają: Pies wrocił się do zmieciska swego i świnia umyta do kałuże błota.

$W$ Abowiem się im przydało ono prawdziwej przypowieści: Pies, ktory się wrocił do zwrocenia swego, i świnia umyta do kałuże błota.

$N$ Aleć się im przydało wedle prawdziwej przypowieści: Pies wrocił się do zwrocenia swego i świnia umyta do kałuże błota.

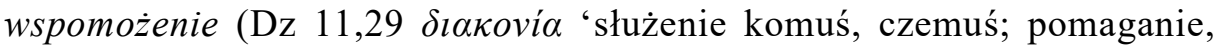
służba, usługa; posługa; posługiwanie; pomoc materialna; urząd diakona'; $B, N$ ratunk; $W$ postugowanie)

$Q$ A uczniowie, jako kto miał, postanowili każdy posłać na wspomożenie braciej, ktorzy mieszkali w Judskiej Ziemi.

$G$ Tedy uczniowie, każdy z nich według przemożenia swego, postanowili posłać na wspomożenie braci, ktorzy mieszkali w Judzkiej Ziemi.

$B$ A tak wszyscy zwolennicy, jako ktory mogł wystarczyć, postanowili posłać nieco na ratunek braciej, ktorzy mieszkali w Żydostwie.

$N$ A z uczniow, jako ktory przemogł, postanowili z nich wysłać na ratunek braciej, ktorzy mieszkali w judskiej ziemi.

$W$ A uczniowie, jako kto miał, postanowili każdy posłać na posługowanie braciej, ktorzy mieszkali w Żydowskiej Ziemi.

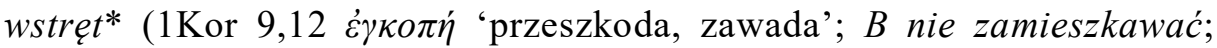
$W$ nie dać przeszkody; $N$ omieszkania nie podali)

$Q \quad$ Jeśli inszy tej wolności nad wami używają, czemuż nie raczej my? Lecześmy tej wolności nie używali, ale wszystko znaszamy, abyśmy jakiego wstrętu Ewanielijej Chrystusowej nie dali.

$G$ Jeźliż insi tej wolności nad wami używają, czemuż nie raczej my? A wszakżeśmy tej wolności nie używali, ale wszystko znaszamy, abyśmy jakiego wstrętu Ewangielii Chrystusowej nie uczynili.

$B$ Jesliż inszy tej mocy nad wami używają, czemuż nie więcej my? A wżdyśmy tej mocy nie używali, ale wszytki rzeczy cierpiemy, abychmy nic nie zamieszkawali Ewanjelijej Krystusowej.

$W$ Jeśli inszy mocy nad wami są uczestnikami, czemu nie raczej my? Lecześmy tej mocy nie używali, ale wszystko znaszamy, abyśmy jakiej przeszkody Ewanielijej Chrystusowej nie dali.

$N$ Jeśliż inszy tej mocej nad wami używają, czemuż nie raczy my? Wszakżeśmy tej wolności nie używali, ale wszytko z nami, abyśmy ktorego omieszkania Ewangelijej Chrystusowej z siebie nie podali. 
załatanie (Mt 9,16 $\pi \lambda \dot{\eta} \rho \omega \mu \alpha$ 'wypełnienie, napełnienie; uzupełnienie, dopełnienie; pełnia, całkowitość; doskonałość, całość; pełność, obfitość'; $B, W$ płat; $N$ wypetnienie)

$Q$ A żaden nie wprawuje płata grubego sukna w wiotchą szatę. Abowiem ono załatanie obrywa nieco od szaty, i zstawa się gorsze przedarcie.

$G$ A żaden nie wprawuje łaty sukna nowego w szatę wiotchą, albowiem ono załatanie ujmuje nieco od szaty, i stawa się gorsze rozdarcie.

$B$ A teżci nikt nie wpuszcza płata nowo uczynionego sukna w wiotchą szatę, abowiem on płat jej ujmuje nieco z szaty i stawa się gorsze przedarcie.

$W$ A teżci nikt nie wpuszcza płata nowo uczynionego sukna w wiotchą szatę, abowiem on płat jej ujmuje nieco z szaty i stawa się gorsze przedarcie.

$N$ A żaden nie wprawuje łaty sukna niefolowanego w wiotchą szatę, abowiem ono wypełnienie ujmuje nieco od szaty i stawa się gorsze przedarcie.

2) czasowniki

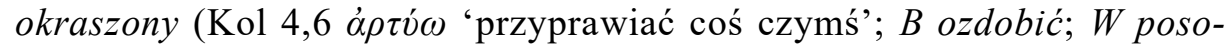
lony; $N$ przyprawiony)

$Q$ Mowa wasza niech zawsze będzie przyjemna, solą okraszona, abyście widzieli, jako macie każdemu z osobna odpowiedzieć.

$G$ Mowa wasza niech zawsze będzie przyjemna, solą okraszona, abyście wiedzieli, jakobyście każdemu z osobna odpowiedzieć mieli.

$B$ Mowa wasza niechaj będzie zawsze $\mathrm{z}$ łaską ozdobiona solą, abyście wiedzieli, jako macie każdemu odpowiedzieć.

$W$ Mowa wasza zawsze w przyjemności niech będzie solą posolona, abyście widzieli jako macie każdemu odpowiedzieć.

$N$ Mowa wasza niech zawsze będzie przyjemna, solą przyprawiona, abyście wiedzieli, jako macie każdemu z osobna odpowiedzieć.

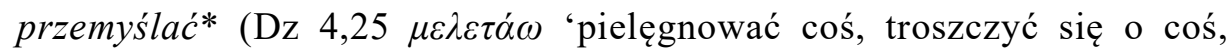
pilnie zajmować się czymś; zastanawiać się nad czymś, martwić się czymś'; $B, N$ zmyślać; W rozmyślać)

$Q$ Ktoryś Duchem świętym przez usta ojca naszego Dawida sługi twego powiedział: Przeczże się narody zburzyły, a ludzie prożne rzeczy przemyślali?

$G$ Ktoryś Duchem Świętym przez usta Dawida, sługi swego, powiedział: Przeczże się zburzyli narodowie, a ludzie prożne rzeczy przemyślali?

$B$ Ktoryś przez usta Dawida, sługi swego, powiedział: Przeczże wzburzyli pogani, a narodowie zmyslali rzeczy prożne?

$N$ Ktoryś Duchem Świętym przez usta Dawida sługi swego powiedział: Przeczże się narody zburzyły, a ludzie prożne rzeczy zmyślali?

$W$ Ktoryś Duchem świętym przez usta ojca naszego Dawida sługi twego powiedział: Czemu się narody wzburzyły, a ludzie prożne rzeczy rozmyślali 


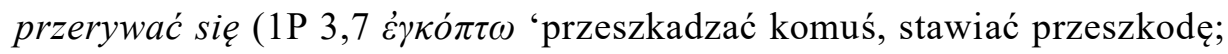
doznawać przeszkód'; B być przekazanym; $W$ przeszkadzać się; $N$ być przeszkadzanym)

$Q$ Także mężowie, mieszkając z nimi wedle umiejętności, wyrządzając uczciwość jako słabszemu naczyniu niewieściemu, jako też spolnym dziedziczkam laski żywota, aby się nie przerywały modlitwy wasze.

$G$ Także i wy, mężowie! mieszkajcie z niemi umiejętnie, a jako mdlejszemu naczyniu niewieściemu oddawajcie uczciwość, jako też społdziedziczkom łaski żywota, aby się modlitwy wasze nie przerywały.

$B$ Także mężowie niech $\mathrm{z}$ nimi mieszkają, jako należy rozumnym, wyrządzając cześć niewieście, jako naczyniu mdlejszemu, i jako społeczni dziedzicy łaski żywota, aby modlitwy wasze nie były przekazane.

$W$ Także mężowie, społmieszkając wedle umiejętności, jako słabszemu naczyniu niewieściemu, wyrządzając uczciwość, jako też spolnym dziedziczkami łaski żywota, aby się nie przeszkadzało modlitwam waszym.

$N$ Także mężowie niech z nimi mieszkają wedle umiejętności, wyrządzając cześć jako mdlejszemu naczyniu niewieściemu, jako też społdziedzicy łaski żywota, aby modlitwy wasze nie były przeszkadzane.

rozpuszczać* (Mt 23,5 $\mu \varepsilon \gamma \alpha \lambda v ́ v \omega$ 'czynić wielkim, zwiększać; wzrastać; wynosić, uwielbiać, sławić, chwalić’; $B, N$ przedlużać; $W$ czynić więtszym)

$Q$ A wszytkie sprawy swe czynią, aby byli widziani od ludzi. Abowiem rozszerzają bramy swe i rozpuszczają kraje.

$G$ A wszystkie uczynki swoje czynią, aby byli widziani od ludzi, i rozszerzają bramy swoje, i rozpuszczają podołki płaszczow swoich.

$B$ Owszem wszytki sprawy swe czynią, aby byli widzeni od ludzi, abowiem rozszyrzają bramy swe popisane i przedłużają podołki płaszczow swoich.

$W$ A wszystkie sprawy swe czynią, aby byli widziani od ludzi. Abowiem rozszerzają bramy swe, i więtsze czynią kraje.

$N$ A wszytkie sprawy swe czynią, aby byli widziani od ludzi i rozszyrzają bramy swe i przedłużają padołki płaszczow swoich.

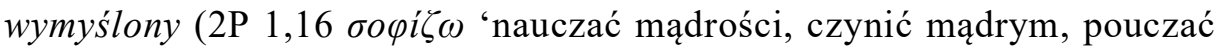
kogoś; pass. być wyrozumowanym, być wymyślanym'; B zmyślony; $W m i$ sterny; $N$ ozdobić mądrościa);

$Q$ Abowiem oznajmiliśmy wam moc i przyszcie Pana naszego, nieuwiedzieni baśniami misternie wymyślonymi, ale przypatrzywszy się sami wielmożności jego.

$G$ Albowiem nie baśni jakich misternie wymyślonych naśladując, uczyniliśmy wam znajomą Pana naszego, Jezusa Chrystusa, moc i przyjście, ale jako ci, ktorzyśmy oczami naszemi widzieli wielmożność jego.

$B$ Abowiem nie oznajmiliśmy wam mocy i przyścia Pana naszego, Jezu Krysta, bawiąc się baśniami zmyślonymi, ale oglądawszy oczyma naszymi majestat jego. 
$W$ Abowiem oznajmiliśmy wam moc i obecność Pana naszego, nieuwiedzeni baśniami misternymi, ale przypatrzywszy się sami wielmożności jego.

\section{3) przymiotniki}

hojny* (Rz 15,29 $\pi \lambda \eta \dot{\rho} \omega \mu \alpha$ 'wypełnienie, napełnienie; uzupełnienie, dopełnienie; pełnia, całkowitość; doskonałość, całość; pełność, obfitość'; $B, N z u$ petny; $W$ obfitość)

$Q \quad$ A wiem, iż przyszedszy do was, z hojnym błogosławieństwem Christusowym przyjdę.

$G \quad$ A wiem, iż gdy przyjdę do was, z hojnem błogosławieństwem Ewangielii Chrystusowej przyjdę.

$B$ A wiemci, iż gdy do was przyjdę, z zupełnym błogosławieństwem Ewanjelijej Krystusowej przyjdę.

$N$ A wiem, iż gdy do was przyjdę z zupełnym błogosławieństwem Ewangelijej Chrystusowej przyjdę.

$W$ A wiem, iż przyszedszy do was, w obfitości błogosławieństwa Ewanieljej Chrystusowej przydę.

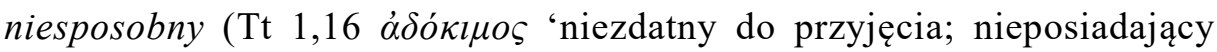
próby, niewypróbowany; stąd: bezwartościowy'; B godzić się; W nikczemny; $N$ niedoświadczony)

$Q$ Wyznawając, iż Boga znają, lecz się uczynkami zapierają, będąc obrzydłymi i nieposłusznymi, a do każdego uczynku dobrego niesposobnemi.

$G$ Udawają, że Boga znają, ale uczynkami swemi tego się zapierają, będąc obrzydłymi i nieposłusznymi, a do wszelkiego dobrego uczynku niesposobnymi.

$B$ Wyznawając, iż Boga znają, ale przą się go uczynkami, gdyż są obrzydłymi i nieposłusznymi, i ktorzy się na żaden uczynek dobry nie godzą.

$W$ Wyznawają iż Boga znają, lecz się uczynkami zapierają, będąc obrzydłymi i trudnymi do wierzenia, a do każdego uczynku dobrego nikczemnymi.

$N$ Wyznawając, iż Boga znają, ale się uczynkami przą, będąc obrzydłemi i nieposłusznemi, a w żadnym dobrym uczynku niedoświadczonemi.

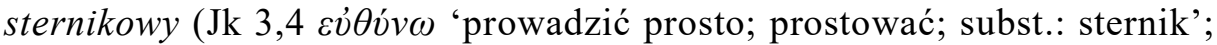
B sprawca; $W, N$ sterujacy)

$Q$ Oto i okręty tak wielkie będąc, i gdy je srogie wiatry pędzą, jednak obracane bywają od malutkiego steru, gdzie jedno jest wola sternikowa.

$G$ Oto i okręty, choć tak wielkie są i tęgiemi wiatrami pędzone bywają, wszak i najmniejszym sterem bywają kierowane, gdziekolwiek jest wola sternikowa.

$B$ Oto też okręty, choć tak wielkie są i od wiatrow gwałtownych pędzone bywają, maluczki rudel obraca, gdziekolwiek chce chuć sprawce.

$W$ Oto i okręty wielkie będąc, i gdy je srogie wiatry pędzą, obracane bywają od malutkiego steru, gdzie wola styrującego zechce. 
$N$ Oto i okręty, choć tak wielkie są, choć je srogie wiatry pędzą, obracane bywają od maluczkiego styru, gdzie wola styrującego zachce.

wystawny (Kol 2,4 $\pi \imath \theta \alpha v o \lambda o \gamma i \alpha$ 'mówienie w sposób przekonujący, sugestywny; biegłość sugestywnego mówienia'; $Q, G$ mowa wystawna; $B$ słowo tagodne; $W$ wyniostość mowy; $N$ mowa dowodna)

$Q \quad$ A toć powiedam, aby was nikt nie podchodził przez wystawną mowę.

$G$ A toć mówię, aby was nikt fałszywemi dowodami nie oszukał przez wystawną mowę.

$B$ A toć powiedam, iżby nikt was nie oszukawał łagodnymi słowy.

$W$ A to powiadam, aby was nikt nie podszedł przez wyniosłość mowy.

$N$ A toć mówię, aby kto was nie podchodził przez dowodną mowę.

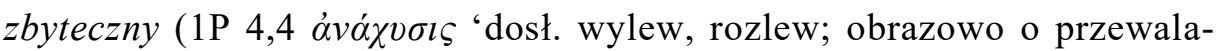
jącej się rzece rozwiązłości’; $B$ zbytek; $W, N$ zbyteczność)

$Q$ Zaczym dziwują się, iż wy nie schadzacie się z nimi ku tejże zbytecznej rozpustności, złorzecząc.

$G$ Przetoż, że się wy z nimi nie schadzacie na taką zbyteczną rozpustę, zda się im rzeczą obcą i bluźnią to.

$B$ A to się im zda coś obcego, iż wy nie biegacie z nimi ku temuż niemiernemu zbytkowi i bluźniąc.

$W$ W czem dziwują się, iż wy nie zbiegacie się ku temuż zbyteczności zamieszaniu, bluźniąc.

$N$ W czym mają sobie za rzecz obcą, iż wy nie zbiegacie się z nimi ku temuż zbyteczności zamieszaniu, bluźniąc.

\section{4) przysłówki}

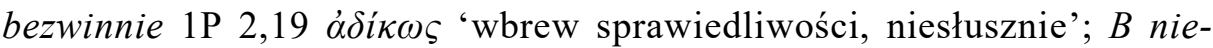
stusznie; $W, N$ niesprawiedliwie)

$Q$ Bo to jest łaska, jeśli kto dla sumnienia Bożego odnosi frasunku, cierpiąc bezwinnie.

$G$ Boć to jest łaska, jeśli kto dla sumienia Bożego ponosi frasunki, cierpiąc bezwinnie.

$B$ Abowiem to jest rzecz wdzięczna, jeśli kto dla sumnienia Bożego cierpi frasunki, będąc niesłusznie utrapiony.

$W$ Bo to jest łaska, jeśli kto dla sumnienia Bożego odnosi frasunku, cierpiąc niesprawiedliwie.

$N$ Boć to jest łaska, jeśli kto dla sumienia Bożego odnosi frasunki, cierpiąc niesprawiedliwie. 
Przytoczmy raz jeszcze wartości liczbowe - na leksykę swoistą tekstu $G$, uznaną za taką zgodnie z przyjętymi tu założeniami, składa się 338 haseł, które łącznie zostały użyte w tym przekładzie 522 razy. 260 spośród haseł, użytych w tekście $G 440$ razy, to podstawienia leksykalne przywołane w tekście $Q$, które są tożsame z ich odpowiednikami bądź w tekście $W$, bądź w tekście $B$, bądź w tekście $N$ albo też w dwu lub trzech z tych tekstów jednocześnie. Jako takie zostały wykluczone z analizy, bowiem leksyka swoista tekstu $G$ to leksemy niepoświadczone w leksykonach $B, W$ i $N$. Natomiast w 82 miejscach biblijnych podstawienia leksykalne przywołane w tekście $Q$ nie są tożsame z ich odpowiednikami w tekstach $B, W$ i $N$. W sumie takich leksemów jest 78. Leksemy tekstu $Q$ w tym wypadku mogły zatem być wzorcem dla wyborów leksykalnych, jakich dokonywał Daniel Mikołajewski, opracowujący tekst $G$. Jednak, jak wskazują wyniki analizy, tylko w przypadku 22 leksemów (co stanowi 6,5\% wszystkich leksemów swoistych $G$ oraz $28,2 \%$ leksemów swoistych $G$, będących potencjalnie wzorcem dla rozwiązań translacyjnych Daniela Mikołajewskiego), które wystąpiły w 23 miejscach biblijnych tekstu $G$ (co stanowi 4,4\% wszystkich użyć leksemów swoistych $G$ oraz $28 \%$ użyć leksemów swoistych $G$, będących potencjalnie wzorcem dla rozwiązań translacyjnych Daniela Mikołajewskiego), można wnosić, że zostały przejęte do przekładu gdańskiego z tekstu $Q$, pierwszej redakcji Nowego Testamentu Jakuba Wujka. Natomiast w 59 miejscach biblijnych tekstu, w których wystąpiło 56 leksemów swoistych tekstu $G$, Daniel Mikołajewski wprowadza podstawienia leksykalne niezależne od tekstu $Q$. W wypadku 16 leksemów tej grupy leksyki swoistej $G$, które poświadczone są w 16 miejscach biblijnych, ekwiwalenty tekstu $G$ wskazują na relację filiacyjną z czeskim tekstem $K$ jako wzorcem dla rozwiązań leksykalnych zastosowanych w tekście gdańskim.

By móc ocenić w pełni siłę oddziaływania wzorca leksykalnego tekstu $Q$ na tekst redagowany przez Daniela Mikołajewskiego należałoby zbadać pod tym względem ponadto leksykę charakterystyczną ${ }^{19}$, po pierwsze dla tekstów: $1 . G$ i $N$; 2. $G$ i $B ; 3 . G, B$ i $N$, co dowiodłoby ewentualnego wpływu tekstu $Q$ jako wzorca podtrzymującego wybory leksykalne Daniela Mikołajewskiego; po drugie, leksykę charakterystyczną dla tekstów: $1 . G$ i $W$; 2. $G, N$ i $W$; 3. $G, B$ i $W$, co pozwoliłoby na ocenę, w ilu przypadkach Daniel Mikołajewski w swoich pracach redakcyjnych podtrzymał wzorce utrwalone

\footnotetext{
${ }^{19}$ Przez leksykę charakterystyczną rozumiem tę część leksykonu $G$, która jest poświadczona jeszcze w jednym lub w jeszcze w dwu z trzech zestawianych z leksykonem $G$ leksykonów renesansowych przekładów Nowego Testamentu, to jest $B, W, N$.
} 
m.in. w tekście $W$, rezygnując z tych ekwiwalentów zaświadczonych w tekście $Q$, które jako nietożsame $\mathrm{z}$ ich odpowiednikami w tekście $W$ mogły być alternatywnym wzorcem leksykalnym dla tekstu $G$. Tego typu analiza uwzględniająca także inne wcześniejsze przekłady, jak choćby Szymona Budnego i Marcina Czechowica jako wzorce ewentualnych rozwiązań leksykalnych przyjętych przez Daniela Mikołajewskiego, wykracza poza ramy tego opracowania.

Tymczasem jednak możemy stwierdzić, że w zakresie leksyki swoistej $G$, jak wykazała prezentowana analiza, ewentualna zależność filiacyjna ewangelickiego Nowego Testamentu Biblii gdańskiej (1632) od katolickiego Nowego Testamentu Jakuba Wujka (1593) jest wprawdzie niewielka, ale w świetle przytoczonych danych empirycznych prawdopodobna.

\section{BIBLIOGRAFIA}

\section{Teksty źródłowe (układ chronologiczny)}

\section{0 - Textus Receptus}

Novum Testamentum Graece. Ed. Robert Stephanus (Estienne), Robert Estienne, 1550, 15 września 2018, https://biblehub.com/tr/matthew/1.htm. Dostęp 15.09.2019.

Grecko-polski Nowy Testament. Wydanie interlinearne z kodami gramatycznymi. Tłum. Remigiusz Popowski, Michał Wojciechowski, Vocatio, 1995.

1563 - Biblia brzeska, skrót: $B$

Brester Bibel 1563, Rothe, red. Hans and Friedrich Scholz, t. 1-2. Ferdinand Schöningh, 2001.

1593 - Nowy Testament Biblii kralickiej, skrót: $K$

Nový Zákon. Tłum. Jan Blahoslav i Jan Němčanský, [brak danych], 1593, https://reader.digitalesammlungen.de/de/fs1/object/display/bsb10861207_00001.html. Dostęp 15.09.2019.

1593 - Nowy Testament Jakuba Wujka, skrót: $Q$

Nowy Testament Pana Naszego Jezusa Chrystusa, znowu z łacińskiego i gręckiego na polskie wiernie a szczyrze przetożony [...]. Tłum. Jakub Wujek, Oficyna Wydawnicza: Andrzej Piotrkowczyk, 1593.

1599 - Biblia Jakuba Wujka, skrót: $W$

Biblia, to jest Księgi Starego i Nowego Testamentu, wedtug lacińskiego przekładu starego, w Kościele powszechnym przyjętego, na polski język znowu z pilnościa przełożone, z dokładaniem tekstu żydowskiego i greckiego i z wyktadaniem katolickim trudniejszych miejsc do obrony wiary świętej powszechnej przeciw kacerztwom tych czasow należacych [...]. Tłum. Jakub Wujek, Drukarnia Łazarzowa: Jan Januszowski, 1599.

1606 - Nowy Testament gdański, skrót: $N$

Nowy Testament Pana Naszego Jezusa Chrystusa z greckiego na polski język z pilnościa przetożony. A teraz znowu przejźrzany $i$ z dozwoleniem Starszych wydany, red. Daniel Mikołajewski, Teofil Turnowski, Wdowa po Guilhelmie Guilmothanie, 1606. 
1632 - Biblia gdańska, skrót: $G$

Biblia Święta, to jest księgi Starego i Nowego Przymierza z żydowskiego i greckiego języka na polskie pilnie i wiernie przetlumaczone. Tłum. Daniel Mikołajewski, Oficyna Andrzeja Hünefelda, 1632.

\section{Słowniki}

Popowski, Remigiusz. Wielki stownik grecko-polski Nowego Testamentu. Wydanie z pelna lokalizacja greckich hasel, kluczem polsko-greckim oraz indeksem form czasownikowych. Vocatio, 1995.

Stownik polszczyzny XVI wieku, t. 1-37. Red. Maria Renata Mayenowa i in., Zakład Narodowy im. Ossolińskich. Wydawnictwo Polskiej Akademii Nauk, 1966-2016.

Vokabulár̆ webový. Webové hnizdo pramenů k poznání historické češtiny. Ústav pro jazyk český Akademie věd České republiky, https://vokabular.ujc.cas.cz/. Dostęp 15.09.2019.

\section{Opracowania}

Czerniatowicz, Janina. Niektóre problemy naukowe grecystyki w pracach biblistów polskich XVI i XVII wieku. Zakład Narodowy im. Ossolińskich, 1969.

Frick, David. Polish Sacred Philology in the Reformation and the Counter-Reformation. Chapters in the History of the Controversies (1551-1632). University of California Press, 1988.

Frick, David. „The Brest Bible of 1563: Translators, Sponsors, Readers. Die Brester Bibel. Kulturgeschichtliche und sprachliche Fragen der Übersetzung”. Brester Bibel 1563, t. 2: Księgi Nowego Testamentu. Kommentare, red. Hans Rothe and Friedrich Scholtz, Ferdinand Schöningh, 2001, ss. 1661-1703.

Kępka, Izabela. „Biblia gdańska - rewizja Biblii brzeskiej czy nowy przekład?”. Rocznik Gdański, nr 14, 2004, ss. 113-123.

Kossowska, Maria. Biblia w języku polskim, t. 1. Księgarnia Świętego Wojciecha, 1968.

Kossowska, Maria. Biblia w języku polskim, t. 2. Księgarnia Świętego Wojciecha, 1969.

Koziara, Stanisław. Frazeologia biblijna w języku polskim. Akademia Pedagogiczna im. Komisji Edukacji Narodowej. Wydawnictwo Naukowe, 2001.

Koziara, Stanisław. Tradycyjne biblizmy a nowe polskie przekłady Pisma Świętego. Wydawnictwo Naukowe Uniwersytetu Pedagogicznego, 2009.

Kwilecka, Irena. „Die Brester Bibel. Kulturgeschichtliche und sprachliche Fragen der Übersetzung”. Brester Bibel 1563, t. 2: Księgi Nowego Testamentu. Kommentare, red. Hans Rothe and Friedrich Scholz, Ferdinand Schöningh, 2001, ss. 1485-1660.

Kwilecka, Irena. Studia nad staropolskimi przekładami Biblii. Uniwersytet im. Adama Mickiewicza: Wydział Teologiczny. Polska Akademia Nauki: Wydział Slawistyczny, 2003.

Lisowski, Tomasz. Sola Scriptura. Leksyka Nowego Testamentu Biblii gdańskiej (1632) na tle porównawczym. Ujęcie kwantytatywno-dystrybucyjne. Wydawnictwo Rys, 2010.

Lisowski, Tomasz. „The lexis of the New Testament in the Brest Biblie (1563) as compared to select subsequent Renaissance translations of the Bible into Polish. The possible filiational relation with respect to lexis". East European \& Balkan Studies, vol. 38, no. 3, 2014, ss. 75-118.

Lisowski, Tomasz. Przekłady Jakuba Wujka w odnowie leksyki Nowego Testamentu gdańskiego (1606). Ujęcie dystrybucyjno-kontekstowe. Wydawnictwo Rys, 2018. 
Oberman, Heiko Augustinus. Marcin Luter. Człowiek między Bogiem a diabłem. Tłum. Elżbieta Adamiak. Wydawnictwo Marabut, 1996.

Pietkiewicz, Rajmund. „Hebraica veritas w Biblii brzeskiej”. Studia Iudaica, nr 18, 2015, ss. 197-222.

Pietkiewicz, Rajmund. Biblia Polonorum. Historia Biblii w języku polskim, t. 1: Od początku do 1638 roku. Pallotinum, 2016.

Sipayłło, Maria. „W sprawie genezy Biblii gdańskiej”. Reformacja w Polsce, nr 6, 1934, ss. 144-151.

Sipayłło, Maria. „Daniel Mikołajewski”. Polski słownik biograficzny, red. Władysław Konopczyński i in., t. 21, Wydawnictwo Zakładu Narodowego im. Ossolińskich, ss. 154-156.

Smereka, Władysław. „Wstęp”. Nowy Testament w przekładzie ks. dra Jakuba Wujka T. J. z r. 1593. Tłum. Władysław Smereka, Polskie Towarzystwo Teologiczne, 1966, ss. VII-XLVIII.

Szeruda, Jan. Geneza i charakter Biblii gdańskiej. Drukarnia „Głosu Ewangelickiego”, 1932.

Uglorz, Manfred. Marcin Luter, ojciec Reformacji. Wydawnictwo Augustana, 1995.

Winiarska-Górska, Izabela. Szesnastowieczne przekłady Pisma Świętego na język polski (15511599) jako gatunek nowożytnej książki formacyjnej. Uniwersytet Warszawski: Wydział Polonistyki, 2017.

Winiarska-Górska, Izabela. „Wulgata - z dziejów terminu i pojęcia”. W labiryncie polszczyzny. Profesorowi Stanisławowi Dubiszowi - doktorzy i doktoranci, red. Beata Jędryka i Ewelina Kwapień, Dom Wydawniczy Elipsa, ss. 29-47.

Wojak, Tadeusz. „Studium o Biblii gdańskiej”. Z Problemów Reformacji, nr 5, 1985, ss. 17-47.

\section{LEKSEMY SWOISTE NOWEGO TESTAMENTU BIBLII GDAŃSKIEJ (1632) WOBEC LEKSYKI NOWEGO TESTAMENTU JAKUBA WUJKA (1593)}

\section{Streszczenie}

Celem artykułu jest próba odpowiedzi na pytanie, w jakim stopniu leksyka swoista Nowego Testamentu Biblii gdańskiej (1632) w przekładzie Daniela Mikołajewskiego wywodzi się z Nowego Testamentu w przekładzie Jakuba Wujka (1593).

Leksemy swoiste Nowego Testamentu Biblii gdańskiej (1632) to te autosemantyczne hasła leksykonu tego tekstu, które nie wystąpiły w leksykonach trzech zestawianych z przekładem gdańskim z 1632 roku wcześniejszych renesansowych przekładów Nowego Testamentu, a mianowicie w przekładach kręgu ewangelickiego - w Nowym Testamencie Biblii brzeskiej (1563), w Nowym Testamencie gdańskim (1606) oraz w jezuickim Nowym Testamencie Biblii Jakuba Wujka (1599).

Analiza wykazała, że w zakresie leksyki swoistej ewangelickiego Nowego Testamentu Biblii gdańskiej z 1632 ewentualna zależność filiacyjna tego przekładu od katolickiego Nowego Testamentu Jakuba Wujka z 1593 roku choć jest niewielka, to empirycznie prawdopodobna.

Słowa kluczowe: thumaczenia Biblii; Nowy Testament Biblii gdańskiej (1632); Nowy Testament Jakuba Wujka (1593); intertekstualność; leksemy swoiste w tłumaczeniach Biblii. 


\section{SPECIFIC LEXEMES OF THE GDAŃSK BIBLE'S NEW TESTAMENT (1632) IN VIEW OF THE LEXIS OF THE NEW TESTAMENT RENDERED BY JAKUB WUJEK (1593)}

\section{Summary}

The purpose of the paper is to examine to what extent so called specific lexis of the Gdańsk Bible's New Testament (1632) rendered into Polish by the evangelical preacher Daniel Mikołajewski is dependent upon the lexis of the New Testament (1593) rendered by the Jesuit Jakub Wujek.

Specific lexemes of the Gdańsk Bible's New Testament (1632) it the ones autosemantic entries of the lexicon of the Gdańsk rendering text, which did not occur either in the lexicon of the New Testament of the Brest Bible (1563) or in the lexicon of the Gdańsk New Testament (1606), the two earlier renderings of the evangelical tradition, as well as in the lexicon of the New Testament of the Bible rendered by the Jesuit Jakub Wujek (1599).

The analysis presented in the paper has led to the conclusion that the filial intertextual relationship between Daniel Mikołajewski's evangelical rendering (1632) and the Catholic Jakub Wujek's rendering (1593) in the terms of the specific lexis of the Gdańsk Bible's New Testament should be considered as the one of relatively low importance but proved empirically.

Key words: rendering of the Bible; the New Testament of the Gdańsk Bible (1632); the Jakub Wujek's New Testament (1593); lexical intertextual relationship; specific lexis of a Bible rendering. 